\title{
Plant $\beta$-diversity in human-altered forest ecosystems: The importance of the structural, spatial, and topographical characteristics of stands in patterning plant species assemblages
}

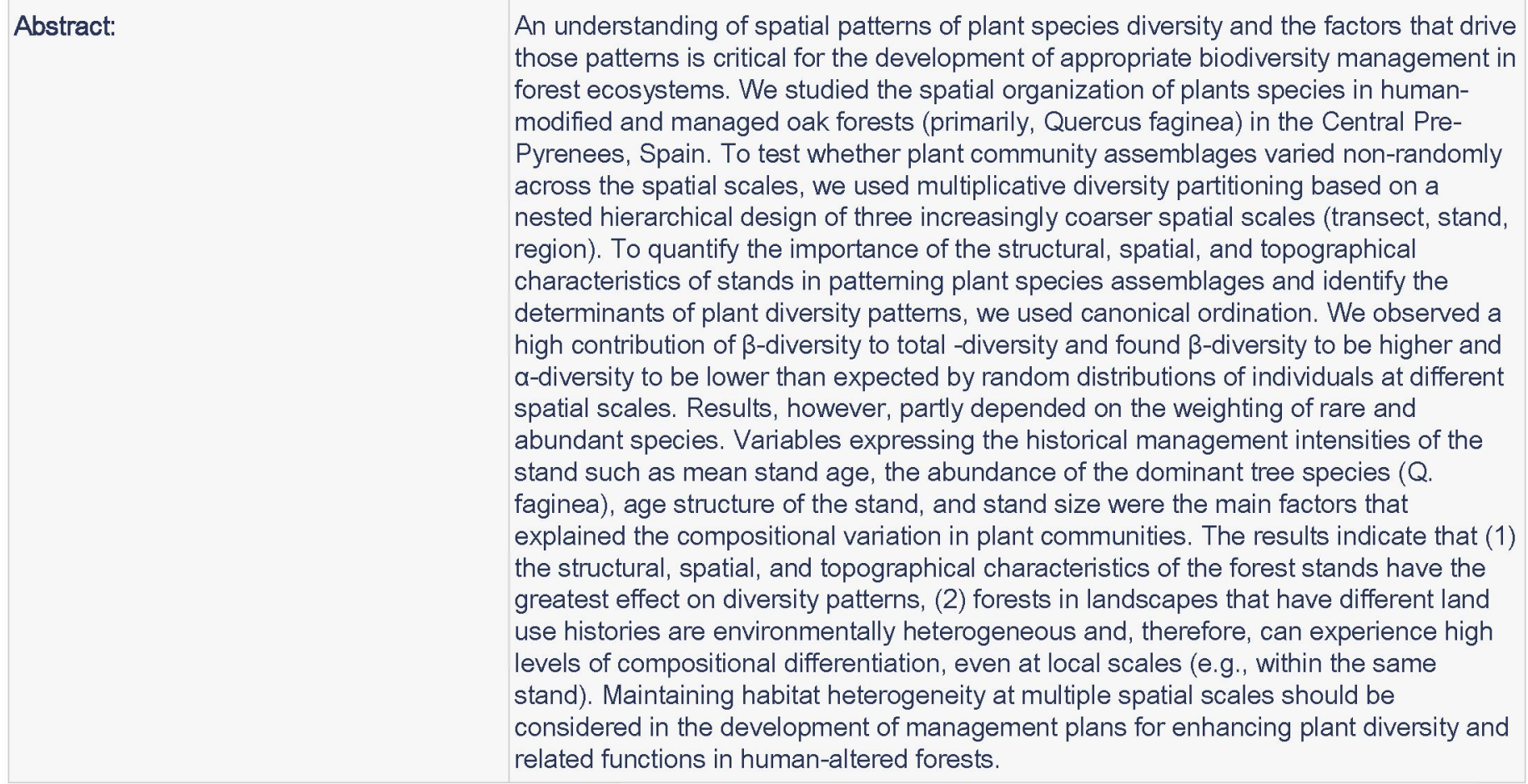




\section{Plant $\beta$-diversity in human-altered forest ecosystems: The importance of the structural, spatial, and topographical characteristics of stands in patterning plant species assemblages}

Yacine Kouba • Felipe Martínez-García • Ángel de Frutos • Concepción L. Alados 
An understanding of spatial patterns of plant species diversity and the factors that drive those patterns is critical for the development of appropriate biodiversity management in forest ecosystems. We studied the spatial organization of plants species in human-modified and managed oak forests (primarily, Quercus faginea) in the Central Pre-Pyrenees, Spain. To test whether plant community assemblages varied non-randomly across the spatial scales, we used multiplicative diversity partitioning based on a nested hierarchical design of three increasingly coarser spatial scales (transect, stand, region). To quantify the importance of the structural, spatial, and topographical characteristics of stands in patterning plant species assemblages and identify the determinants of plant diversity patterns, we used canonical ordination. We observed a high contribution of $\beta$-diversity to total $\gamma$ diversity and found $\beta$-diversity to be higher and $\alpha$-diversity to be lower than expected by random distributions of individuals at different spatial scales. Results, however, partly depended on the weighting of rare and abundant species. Variables expressing the historical management intensities of the stand such as mean stand age, the abundance of the dominant tree species ( $Q$. faginea), age structure of the stand, and stand size were the main factors that explained the compositional variation in plant communities. The results indicate that (1) the structural, spatial, and topographical characteristics of the forest stands have the greatest effect on diversity patterns, (2) forests in landscapes that have different land use histories are environmentally heterogeneous and, therefore, can experience high levels of compositional differentiation, even at local scales (e.g., within the same stand). 
Maintaining habitat heterogeneity at multiple spatial scales should be considered in the development of management plans for enhancing plant diversity and related functions in human-altered forests. 


\section{Introduction}

Most studies of forest ecosystems focused on $\alpha$-diversity, i.e., the diversity within a specific site; however, recent studies that have partitioned diversity into hierarchical components have shown that much of the plant diversity is due to differentiation in species composition among sites ( $\beta$-diversity; Arroyo-Rodríguez et al., 2013; Chandy, Gibson, \& Robertson, 2006; Gossner et al., 2013). Particularly in human-altered forests, the assessment of plant diversity patterns across multiple spatial scales and the identification of the factors that drive those patterns is required to accurately evaluate the impact of historical man-induced disturbances on the spatial dissimilarities in species composition ( $\beta$-diversity) and to gain a better understanding of the mechanisms that contribute to the maintenance of species diversity in this type of forests (Arroyo-Rodríguez et al., 2013).

In human-altered forests, the structural, spatial, and topographical characteristics of the stand, which are strongly influenced by historical land usetype and intensity, might have a significant role in shaping plant diversity patterns (Flinn and Vellend 2005; Hermy and Verheyen 2007; Berhane et al. 2013). Recent studies have found that forest stands in landscapes that have different land use histories manifest a high environmental heterogeneity, which can lead to high levels of compositional differentiation (i.e., $\beta$-diversity) even at fine scales (e.g. ArroyoRodríguez et al. 2013). The floristic differentiation can drive successional trajectories and potentially affect the maintenance of biodiversity in such altered forests (Chazdon 2008; Chazdon et al. 2009; Melo et al. 2013; Arroyo-Rodríguez et 


\section{al. 2013).}

For centuries, the oak forests (mainly, Quercus faginea) in the western Mediterranean region have been harvested intensively for timber and firewood, and clearcut for agriculture (Sancho et al. 1998), which has reduced them to coppice stands that have different management histories; i.e., different coppicing intensities and time since coppicing ceased (Sancho et al. 1998). In the late 19th and 20th centuries, however, changes in socioeconomic structures and production systems resulted in the abandonment of the poorest arable lands and their subsequent afforestation (Sciama et al. 2009). In particular, in the Central Pyrenees, Spain, the encroachment of some abandoned farmlands by $Q$. faginea has led to new, secondary growth Q. faginea-dominated stands (Kouba et al. 2012). Although most of these forests (i.e., either the formerly managed or the new secondary growth forests) are deprived of any conservation status, they provide habitats for a wide diversity of plant and animal communities (Kouba and Alados 2011), which enables them to recover many components of the original biodiversity, and provide important ecosystem services such as control of climate and erosion. The management of these forests for biodiversity conservation and ecologically sustainable services is, therefore, of great interest (Kouba and Alados 2011).

In this study, we used multiplicative diversity partitioning to understand how plant species diversity changes across three spatial scales (transect, stand, and region) as well as to identify the spatial scales at which nonrandom processes have had the greatest effect. In addition, we used constrained ordination analysis to 
identify the forest structural and environmental factors that might have patterned plant species diversity in human-modified and managed oak forests. We hypothesized that (H1) plant community assemblages vary non-randomly across the spatial scales, (H2) $\beta$-diversity components contribute more to $\gamma$-diversity than do $\alpha$-diversity components because of high habitat heterogeneity, and (H3) the structural properties, spatial attributes, and topographical conditions of the forest stands are the main factors that structure the compositional variation in plant communities in these human-modified and managed forests.

\section{Methods}

Study area

The study was conducted within a $1363-\mathrm{km}^{2}$ area in the Central Pre-Pyrenees, Spain (between $42.32 \mathrm{~N}$ to $42.11 \mathrm{~N}$, and $0.31 \mathrm{~W}$ to $0.04 \mathrm{~W}$ ) (Fig. 1). The lithology is mostly conglomerate, limestone, marl, and sandstone developed on Eocene flysch sedimentary formations (Kouba and Alados 2011). The climate is transitional subMediterranean; i.e., influenced by continental effects from the Pyrenees to the north and by milder Mediterranean conditions that prevail from the south (i.e., the Ebro Basin). In the study area, mean annual precipitation is $1317 \pm 302 \mathrm{~mm}(1915-2005)$ (Kouba et al. 2012) and mean annual air temperature is $11.5 \pm 2.8^{\circ} \mathrm{C}(1910-2005)$ (Kouba et al. 2012). 
The area has a variety of land use types including natural forests of Pinus sylvestris, P. nigra, Fagus sylvatica, Q. ilex, and $Q$. faginea, shrublands of $Q$. coccifera and Buxus sempervirens, artificial plantations of P. sylvestris and P. nigra, arable farmland, pastures (xeric pastures and subalpine pastures), urban areas, and abandoned farmland. In the second half of the twentieth century, major changes in land use occurred in the area (Lasanta et al. 2005) because of agricultural mechanization and intensification, the introduction of pine plantations, and the abandonment of croplands and pastures, which has led to forest regrowth (Lasanta et al. 2005; Vicente-Serrano et al. 2010). In the area, Q. faginea is one of the most abundant naturally occurring species and the communities in which it occurs constitute a transition zone between Mediterranean forests in which Q. ilex ssp. ballota or P. halepensis are predominant, and mountain continental or mesic forests of P. sylvestris, P. nigra ssp. salzmannii, and F. sylvatica (Loidi and Herrera 1998; Sancho et al. 1998). The overstorey canopy of those semi-deciduous oak stands is dominated by $Q$. faginea interspersed with some scattered pines (Pinus sylvestris and P. nigra) and evergreen oak ( $Q$. ilex subsp. ballota). The understory is composed of shrubs (Q. coccifera, B. sempervirens, Genista scorpius, Juniperus communis), forbs (Aphyllanthes monspeliensis, Arenaria montana, Achillea millefolium), and graminoids (Brachypodium pinnatum, Carex halleriana, Festuca rubra, Carex flacca, Bromus erectus).

Stand selection and data collection 
Based on the distribution maps of Q. faginea in the study area in 1957 and 2006 (Kouba and Alados 2011) and dendrochronological data that reflect the historical dynamics of Q. faginea stands in the study area (Kouba et al. 2012), ten Q. fagineadominated stands that differed in their structural, spatial, and topographical characteristics were selected within the study area (see Table 1, Fig. 1). Primarily, the stands were surrounded by farmland, pine plantations, abandoned land, and grassland (see Fig. 1).

In 2009 and 2010, during the period of peak growth (May and June), the vascular plant species were surveyed in the ten stands. Within each stand, three 500-m linear transects (30 transects in total) were established (hereafter, floristic transects). To estimate plant abundance and richness within each transect, we used the PointIntercept Method (Goodall 1952), which involves recording, at $40-\mathrm{cm}$ intervals, the identity of all individuals that are in contact with a vertical nail (Alados et al. 2009). We recorded all of the vascular plants that touched the nail and any overstorey species (including $Q$. faginea) that were above the nail. The abundance of each species in each transect was estimated as the number of its individuals recorded along the transect. Plant species that could not be identified with certainty in the field were collected, pressed, and brought to the laboratory for identification by botanical experts. Species that have traits that make them difficult to distinguish were only identified to the genera level. Plant nomenclature followed "Flora Ibérica" (Castroviejo et al. 1986-2012).

Plant growth forms represent broad patterns of variation among correlated plant traits that are more related to ecosystem functions, e.g. nutrient use efficiency, 
protection against abiotic and biotic hazards, and competitive strength (Lavorel et al. 1997; Dorrepaal 2007), and, therefore, are expected to differ in their responses to forest structural and environmental factors. Accordingly, plant species were grouped based on growth forms: woody (tree and shrubs), graminoids, or forbs.

In this study, the relative abundance of $Q$. faginea (QFAB) in each floristic transect was included in the analyses as surrogate for the amount of canopy cover (\%). To quantify the structural properties of each stand (Table 1) a 500-m linear transect (hereafter, forest structure transect) was established within each stand (n $=10$ ) and the forest was sampled using the Point-quarter Method (Cottam and Curtis 1956). Each forest structure transect was placed close to the central floristic transect within each stand. Sampling points $(n=20)$ were at 25 -m intervals along each of the transects. At each sampling point, we identified the closest adult $Q$. faginea tree in each of the four cardinal directions within a maximum distance of 5 $\mathrm{m}$ from the sampling point (Kouba et al. 2012). Adult trees were defined as those $>2$ $m$ high or that had a stem diameter at breast height $(\mathrm{DBH}) \geq 4 \mathrm{~cm}$. The following measurements were recorded: diameter at breast height (DBH) $(\mathrm{cm})$, tree height (m), and age (for details about age estimation, see Kouba et al. 2012). Those data were used to estimate the following variables for each stand: density (DENSITY), mean diameter at breast height (DBH), mean tree height (TREHEIGHT), mean age (AGE), and coefficient of variation of tree age (CVAGE). Furthermore, forest type (FORTYPE; secondary growth stands vs. abandoned coppice stands) was recorded for each stand based on visual observation on the field (see Table 1).

To quantify the spatial attributes of each stand (Table 1), we measured stand size 
(STSIZE) and shape complexity (SHPCOMP) using a digitized Q. faginea distribution map, the 'Patch Analyst' extension in ArcGIS 10.1 (ESRI 2013), the Third National Forest Inventory map (IFN3; MAGMARA, 2013), and orthorectified aerial photographs taken in 2006 (CINTA 2013). In addition, the mean elevation (ELEVAT), mean slope (SLOP), and orientation (ORIENT) of each stand were derived from a Digital Elevation Model (CINTA 2013).

Partitioning of biodiversity

To assess plant diversity patterns across multiple spatial scales, we used multiplicative partitioning because of the advantages of the Hill Number $\left({ }^{q} D\right)$ and $q$ metric (see below): ${ }^{q} D_{\gamma}={ }^{q} D_{\beta} \times{ }^{q} D_{\alpha}$ (Whittaker 1972; Jost 2006, 2007, 2010). Diversity is quantified using the Hill Number $\left({ }^{q} D\right)$, which has the property to be invariant to changes in absolute numbers; if all species double in abundance, ${ }^{q} D$ remains unchanged. It measures variation in relative, rather than absolute abundance, and it follows the replication principle: Combining two sets of nonoverlapping species that have the same abundance distributions doubles the value of $q D$ (Jost 2006; Scheiner 2012). To quantify diversity patterns based on various weightings for rare and abundant species, we used the $q$-metric, which reflects the sensitivity of the diversity index to the relative frequencies of species. The analyses included two $q$-values: (1) $q=0$ reflects species richness, which is not sensitive to species abundance and, therefore, assigns disproportionate weight to rare species (Jost 2006), and (2) $q=0.999$ (and not $q=1$, which would require division by zero) 
is equivalent to the exponential of Shannon entropy; here, species are weighted in proportion to their frequency in the sampled community and, therefore, it can be interpreted as the number of 'typical species' in the community (Chao et al. 2012).

We used a nested hierarchical design of three increasingly coarser spatial scales: individual assemblages at the transect level, pooled assemblages within a stand, and a single, pooled assemblage across the entire region (Fig. 2). The design allowed ${ }^{q} D_{\gamma}$ diversity to be decomposed into within transect ( ${ }^{q} D_{\alpha \_ \text {transects }}$ ), among transects ( ${ }^{q} D_{\beta \_ \text {transects }}$ ), within stand ( ${ }^{q} D_{\alpha \_ \text {stands }}$ ), and among stands ( ${ }^{q} D_{\beta_{\beta} \text { stands }}$ ) components (Fig. 2). To test for significant differences in the spatial partitioning of diversity, the expected values of the measures of diversity were calculated using individual-based randomizations $\left(10^{4}\right.$ permutations; Crist et al. 2003), which evaluated whether the $\alpha$ and $\beta$ components of diversity differed significantly from a random distribution of individuals among samples (Crist et al. 2003). Those analyses were performed using the 'vegan' package (Oksanen et al. 2013) implemented in the R software ( $\mathrm{R}$ Development Core Team 2013).

To test whether differences in species richness might have biased the observed spatial diversity pattern, we additively partitioned $\beta$-diversity into the two components of spatial turnover and nestedness using the method suggested by Baselga (2010). We performed this analysis using the 'betapart' package (function 'beta.sample') (Baselga and Orme 2012) within the R software (R Development Core Team 2013).

Partitioning the variation in plant communities in response to forest structural and 
environmental factors

To identify the variables that explained a significant amount of the variation in species composition, we used Canonical Redundancy Analyses (RDA). The matrices of species abundance were Hellinger transformed prior to analysis (Legendre and Gallagher 2001). After this transformation, RDA is based on the Hellinger distance, which is appropriate for community composition data, instead of being based on the inappropriate Euclidean distance (Legendre and Gallagher 2001). The explanatory variables included in the finale RDA models were selected based on forward stepwise procedure, which provided an estimate of the best set of non-redundant variables for predicting species composition and a ranking of the relative importance of the individual explanatory variables.

The spatial autocorrelation of the residuals of the RDA models was tested using a multi-scale ordination (MSO; Borcard et al. 2011; Legendre and Legendre 2012). Initial analyses indicated significant spatial autocorrelation in the residuals of the RDA models and a scale-dependent relationship between the species data and the explanatory variables. To address those problems, the following three steps were followed: (i) the Hellinger-transformed species data matrices and the explanatory variables were detrended along the Y Cartesian geographic coordinates (i.e., the coordinates of transect-central points), which supported the assumption of stationarity in the computation of confidence intervals in the MSO variograms (Legendre and Legendre 2012). (ii) The sampling design was spatially nested; therefore, the function 'create.MEM.model' (Borcard et al. 2011; Declerck et al. 2011) 
was used to construct a staggered spatial matrix of Moran's eigenvector maps (MEM), and (iii) partial canonical redundancy analyses (partial RDAs) were performed using the detrended data and included the computed MEMs as covariables, which controlled for the effects of spatial structure (i.e., excluded the compositional variation caused by spatial structure; Borcard et al. 2011; Legendre and Legendre 2012).

\section{Results}

In the survey of the 10 oak stands in the Central Pre-Pyrenees, Spain, we identified 238 vascular plant species. On average, the floristic transects contained 64 species (range $=43-98$ ). Twenty-one (9\%) of the species contributed $80 \%$ of the total plant coverage by abundance, and B. sempervirens was the most abundant species in all of the stands (Fig. 3). Most of the species were forbs (159 species), followed by woody plants (54 species) and graminoids (25 species). Among rare species (i.e., species that had a relative abundance $<0.01 \%$ and occurred in $<5 \%$ of the transects; see Appendix 1), $75 \%$ were forbs, $7 \%$ were graminoids, and $18 \%$ were woody species.

Patterns of diversity across spatial scales

In general, $\beta$-diversity components ( ${ }^{q} D_{\beta_{-} \text {transects }}$ and ${ }^{q} D_{\beta_{-} \text {stands }}$ ) made up a large proportion of overall diversity (Fig. 4). At all spatial scales, and independently of the value of $q$, $\beta$-diversity was significantly higher, and alpha diversity was significantly 
lower than expected based on a random distribution of individuals (Table 2). $\beta$ diversity and the deviations from random distributions were higher among stands than among transects for the two values of $q(0$ and 1$)$. The two components of $\beta$ diversity $\left({ }^{q} D_{\beta_{-} \text {transects }}\right.$ and $\left.{ }^{q} D_{\beta_{\text {_stands }}}\right)$ declined with increasing values of $q$ (Table 2 ), which reflected the lower emphasis given to rare species as $q$ increases.

The partitioning of $\beta$-diversity into two components, spatial turnover and nestedness, revealed that overall spatial turnover accounted for $>96 \%$ of total $\beta$ diversity, which suggests that bias caused by differences in species richness among transects was negligible.

Partitioning the variation in plant communities in response to forest structural and environmental factors

The explanatory variables selected by the RDA explained a significant amount of the variation in the composition of forbs and woody species (Table 3), but not the composition of graminoids. Collectively, AGE (10.6\%), QFAB (8.9), CVAGE (13.3), and SLOP (11.4) explained $44.2 \%$ of the variation in the composition of forbs species (Table 3). Most of the forbs were common in young and uneven-aged stands, although there were some exceptions, such as Aphyllanthes monspeliensis (APHMON) and Bupleurum rigidum (BUGRA), which were related to lower Q. faginea abundance and higher stand age, respectively, and the perennial species Hepatica nobilis (HEPAT) and Q. faginea abundance were correlated (Fig. 5).

For woody species, STSIZE (11.7\%), QFAB (11.4), AGE (11.5), and CVAGE (9.2) 
explained $43.8 \%$ of the variation in species composition (Table 3). The long-lived shrub B. sempervirens (BUXSEM) was positively correlated with Q. faginea abundance, Genista scorpius (GENSCO), Thymus vulgaris (THYVUL), and Echinospartum horridum (ECHIOR) were prevalent in uneven-aged stands, and others, i.e., Juniperus oxycedrus (JUNOXY) and P. sylvestris (PINSIL), were related to lower Q. faginea abundance. Cytisophyllum sessilifolium (CYTSES), Amelanchier ovalis (AMEOVA), and Arctostaphylos uva-ursi (ARCUVA) predominated in old stands (Fig. $5)$.

\section{Discussion}

Our study is one of the first to assess plant spatial diversity patterns and identify the factors that drive the structuring of plant species composition in human-modified and managed forests. The high contribution of $\beta$-diversity to total $\gamma$-diversity with $\beta$ diversity being significantly higher than expected by chance at all spatial scales, independent of the value of $q$, suggests that changes in species composition, rather than variation in species abundances, are primarily responsible for the spatial diversity patterns, which has been observed elsewhere (Devictor et al. 2010; Gossner et al. 2013). In addition, the fact that $\beta$-diversity was largely due to spatial turnover rather than nestedness, indicates that assemblages in species-poor transects are not a subset of assemblages of species-rich transects.

In our study, among stands $\beta$-diversity was highest when all species were weighted equally $(q=0)$, which corresponds to a stronger influence of rare species 
(i.e., species with small populations). Thus, rare species appeared to have a heterogeneous distribution in the human-modified and managed oak forests; probably, because their habitats had a clumped distribution (Chávez and Macdonald 2012; Gossner et al. 2013, Arroyo-Rodríguez et al. 2013). It should be noted that although the rare species were not really rare (with a conservation status); some of them were forest specialists (with great conservation value).

High structural and environmental heterogeneities caused by differences in stand history and successional stage might have led to the high level of compositional differentiation among stands observed in our study. Indeed, the constrained ordination showed that the structural, spatial, and topographical characteristics of the forest stands explained a high proportion of the compositional variation. Stand age, the age structure distribution, Q. faginea abundance, stand size, and site conditions (i.e., slope) explained most of the spatial variation in composition, particularly, of forbs and woody species. Other studies have shown that forest structure (e.g., stand age, canopy cover), forest spatial attributes (e.g., patch size), and topographical conditions can have important roles in structuring the composition of plant communities in many types of forests worldwide (e.g., Aavik et al. 2009; Vockenhuber et al. 2011; Lomba et al. 2011), mainly, by controlling the availability of resources, particularly light and soil nutrients, and habitat conditions, particularly substrate, temperature, and pH (Härdtle et al. 2003; Aubert et al. 2004; Hart and Chen 2006).

At the finest spatial scale, among transects, the compositional differentiation was higher than expected, based on either rare or typical species, which reflects a degree 
of microhabitat heterogeneity within the same stand (Chávez and Macdonald 2012). The within-stand dissimilarity in canopy cover (i.e. differences in $Q$. faginea abundance among the transects) might be responsible for the microhabitat heterogeneity; i.e., heterogeneity can result from the creation of gaps in the canopy, which might increase the resources available at forest floor and, therefore, provide conditions for the development of species with different niches (Hart and Chen 2006; Fahey and Puettmann 2007; Chávez and Macdonald 2012), which can lead to relatively high rates of species turnover within the same stand (Sabatini et al. 2014).

Implications for management and conservation

Our results clearly demonstrate the importance of $\beta$-diversity components; i.e., among-transects and among-stands $\beta$-diversity, for overall diversity, which underscores the need to consider $\beta$-diversity at all spatial levels including smaller spatial scales when making management plans designed to enhance plant diversity and related functions in human-altered forests. In addition, the high spatial turnover in relation to nestedness suggests that conservation efforts should be concentrated on a large number of not necessarily the richest sites and this is also supported by other studies (e.g. Gossner et al. 2013).

Furthermore, this study has highlighted the importance of stand characteristics in structuring $\beta$-diversity. Keeping a mixture of stands of different structural properties, spatial attributes, and topographical conditions could, therefore, help to enhance plant diversity in these oak forests, and in turn supporting conservation of 
associated faunal communities. Finally, our study points to the importance of maintaining micro-environmental heterogeneity within oak stands (e.g. by creating canopy gaps), to conserve and restore understory plant species richness and diversity.

Acknowledgments We thank Arben Q. Alla, Gabriel Sangüesa-Barreda, Guillermo C. Bueno, Benjamin Komac, Maite Gartzia, Hugo Saiz, and Paloma Nuche for assistance in the field. Y.K. was funded by a MAEC-AECID grant from the Spanish Agency for International Cooperation and Development, and A.F. was supported by a JAE-doc postdoctoral contract from the framework "Junta para la Ampliación de Estudios" (Spanish Ministry of Economy and Competitiveness), co-financed by the European Social Fund. This study was part of the research project CGL2011-27259 (Spanish Ministry of Economy and Competitiveness and Innovation) co-financed by the FEDER.

\section{References}

Aavik T, Püssa K, Roosaluste E, Moora M (2009) Vegetation change in boreonemoral forest during succession - trends in species composition, richness and differentiation diversity. Ann Bot Fennici 46: 326-335.

Alados CL, Navarro T, Komac B, et al. (2009) Do vegetation patch spatial patterns disrupt the spatial organization of plant species? Ecol Complex 6:197-207. doi: 10.1016/j.ecocom.2008.10.015

Arroyo-Rodríguez V, Rös M, Escobar F, et al. (2013) Plant $\beta$-diversity in fragmented rain forests: testing floristic homogenization and differentiation hypotheses. J Ecol 101:1449-1458. doi: $10.1111 / 1365-2745.12153$

Aubert M, Bureau F, Alard D, Bardat J (2004) Effect of tree mixture on the humic epipedon and vegetation diversity in managed beech forests (Normandy, France). Can J For Res 248:233248. doi: $10.1139 / \mathrm{X} 03-205$ 
Baselga A (2010) Partitioning the turnover and nestedness components of beta diversity. Glob Ecol Biogeogr 19:134-143. doi: 10.1111/j.1466-8238.2009.00490.x

Baselga A, Orme CDL (2012) betapart: an R package for the study of beta diversity. Methods Ecol Evol no-no. doi: 10.1111/j.2041-210X.2012.00224.X

Berhane A, Totland $\emptyset$, Moe SR (2013) Woody plant assemblages in isolated forest patches in a semiarid agricultural matrix. Biodivers Conserv 22:2519-2535. doi: 10.1007/s10531-0130534-0

Borcard D, Gillet F, Legendre P (2011) Numerical Ecology with R. Spriger, New York

Castroviejo S et al. 1986-2012. Flora Ibérica. vols 1-8, 10-15, 17-18, 21. Real Jardin Botanico, Madrid, Spain

Chandy S, Gibson DJ, Robertson P a. (2006) Additive partitioning of diversity across hierarchical spatial scales in a forested landscape. J Appl Ecol 43:792-801. doi: 10.1111/j.13652664.2006.01178.x

Chao A, Chiu C-H, Hsieh TC (2012) Proposing a resolution to debates on diversity partitioning. Ecology 93:2037-51.

Chávez V, Macdonald SE (2012) Partitioning vascular understory diversity in mixedwood boreal forests: The importance of mixed canopies for diversity conservation. For Ecol Manage 271:19-26. doi: 10.1016/j.foreco.2011.12.038

Chazdon RL (2008) Beyond deforestation: restoring forests and ecosystem services on degraded lands. Science (80- ) 320:1458-60. doi: 10.1126/science.1155365

Chazdon RL, Peres C a, Dent D, et al. (2009) The potential for species conservation in tropical secondary forests. Conserv Biol 23:1406-17. doi: 10.1111/j.1523-1739.2009.01338.x

CINTA (2013) Centro de Información Territorial de Aragón. http://sitar.aragon.es.

Condit R, Pitman N, Leigh EG, et al. (2002) Beta-diversity in tropical forest trees. Science 295:666-9. doi: $10.1126 /$ science.1066854

Cottam C, Curtis JT (1956) "The use of distance measures in phytosociological sampling."Ecology $37: 451-460$.

Crist T, Veech J, Gering J, Summerville K (2003) Partitioning species diversity across landscapes and 
regions: A hierarchical analysis of $\alpha, \beta$, and $\gamma$ diversity. Am Nat 162:734-743. doi: $10.1086 / 378901$

Declerck SAJ, Coronel JS, Legendre P, Brendonck L (2011) Scale dependency of processes structuring metacommunities of cladocerans in temporary pools of High-Andes wetlands. Ecography (Cop) 34:296-305. doi: 10.1111/j.1600-0587.2010.06462.x

Devictor V, Mouillot D, Meynard C, et al. (2010) Spatial mismatch and congruence between taxonomic, phylogenetic and functional diversity: the need for integrative conservation strategies in a changing world. Ecol Lett 13:1030-40. doi: 10.1111/j.1461-0248.2010.01493.x

Dorrepaal E (2007) Are plant growth-form-based classifications useful in predicting northern ecosystem carbon cycling feedbacks to climate change? J Ecol 95:1167-1180. doi: $10.1111 / \mathrm{j} .1365-2745.2007 .01294 . \mathrm{x}$

ESRI (2013) ArcMap 10.1 Environmental Systems Research Institute Inc.

Fahey RT, Puettmann KJ (2007) Ground-layer disturbance and initial conditions influence gap partitioning of understorey vegetation. J Ecol 95:1098-1109. doi: 10.1111/j.13652745.2007.01283.x

Flinn KM, Vellend M (2005) Recovery of forest plant communities in post-agricultural landscapes. Front Ecol Environ 3:243-250.

Goodall DW (1952) Some considerations in the use of point quadrats for the analysis of vegetation. Aust J Biol Sci 5:1-41. doi:10.1071/BI9520001

Gossner MM, Getzin S, Lange M, et al. (2013) The importance of heterogeneity revisited from a multiscale and multitaxa approach. Biol Conserv 166:212-220. doi: 10.1016/j.biocon.2013.06.033

Härdtle W, von Oheimb G, Westphal C (2003) The effects of light and soil conditions on the species richness of the ground vegetation of deciduous forests in northern Germany (SchleswigHolstein). For Ecol Manage 182:327-338. doi: 10.1016/S0378-1127(03)00091-4

Hart SA, Chen HYH (2006) Understory Vegetation Dynamics of North American Boreal Forests. CRC Crit Rev Plant Sci 25:381-397. doi: 10.1080/07352680600819286

Hermy M, Verheyen K (2007) Legacies of the past in the present-day forest biodiversity: a review of 
past land-use effects on forest plant species composition and diversity. Ecol Res 22:361-371. doi: $10.1007 / \mathrm{s} 11284-007-0354-3$

Jost L (2006) Entropy and diversity. Oikos 113:363-375. doi: 10.1111/j.2006.0030-1299.14714.x

Jost L (2007) Partitioning diversity into independent alpha and beta components. Ecology 88:24272439. doi: $10.1890 / 06-1736.1$

Jost L (2010) Independence of alpha and beta diversities. 91:1969-1974.

Kouba Y, Alados CL (2011) Spatio-temporal dynamics of Quercus faginea forests in the Spanish Central Pre-Pyrenees. Eur J For Res 131:369-379. doi: 10.1007/s10342-011-0509-1

Kouba Y, Camarero JJ, Alados CL (2012) Roles of land-use and climate change on the establishment and regeneration dynamics of Mediterranean semi-deciduous oak forests. For Ecol Manage 274:143-150. doi: 10.1016/j.foreco.2012.02.033

Lasanta T, Vicente-serrano S, Cuadratprats J (2005) Mountain Mediterranean landscape evolution caused by the abandonment of traditional primary activities: a study of the Spanish Central Pyrenees. Appl Geogr 25:47-65. doi: 10.1016/j.apgeog.2004.11.001

Lavorel S, McIntyre S, Landsberg J, Forbes TDA (1997) Plant functional classifications: from general groups to specific groups based on response to disturbance. Trends Ecol Evol 12:474-478. doi: 10.1016/S0169-5347(97)01219-6

Legendre P, Gallagher ED (2001) Ecologically meaningful transformations for ordination of species data. 2001:271-280. doi: 10.1007/s004420100716

Legendre P, Legendre L (2012) Numerical ecology, 3rd ed. Elsevier, New York

Loidi J, Herrera M (1990) The Quercus pubescens and Quercus faginea forests in the Basque Country (Spain): distribution and typology in relation to climatic factors. Vegetacion 90: 81-92.

Lomba A, Vicente J, Moreira F, Honrado J (2011) Effects of multiple factors on plant diversity of forest fragments in intensive farmland of Northern Portugal. For Ecol Manage 262:2219-2228. doi: 10.1016/j.foreco.2011.08.014

MAGMARA (2013) Tercer Inventario Forestal Nacional (IFN3) 1:50 000. Madrid, Spain Melo FPL, Arroyo-Rodríguez V, Fahrig L, et al. (2013) On the hope for biodiversity-friendly tropical landscapes. Trends Ecol Evol 28:462-8. doi: 10.1016/j.tree.2013.01.001 
Oksanen J, F. Guillaume Blanchet RK, Legendre P, et al. (2013) vegan: Community Ecology Package. R package version 2.0-7.

R Development Core Team (2013) R: A language and Environment for Statistical Computing. R Foundation for Statistical Computing, Vienna, Austria. ISBN3-900051-07-0, Available at URL: http://www.R-project.org.

Sabatini FM, Burrascano S, Tuomisto H, Blasi C (2014) Ground layer plant species turnover and Beta diversity in southern-European old-growth forests. PLoS One 9:e95244. doi: 10.1371/journal.pone.0095244

Sancho M, Fernández P, Albertos S, LG S (1998) Regiones de procedencia de Quercus pyrenaica Willd. Quercus faginea Lam. Quercus canariensis Willd. OAPN, Madrid

Scheiner SM (2012) A metric of biodiversity that integrates abundance, phylogeny, and function. Oikos 121:1191-1202. doi: 10.1111/j.1600-0706.2012.20607.x

Sciama D, Augusto L, Dupouey J-L, et al. (2009) Floristic and ecological differences between recent and ancient forests growing on non-acidic soils. For Ecol Manage 258:600-608. doi: 10.1016/j.foreco.2009.04.027

Vicente-serrano SM, Lasanta T, Gracia C (2010) Agricultural and Forest Meteorology Aridification determines changes in forest growth in Pinus halepensis forests under semiarid Mediterranean climate conditions. Agric For Meteorol 150:614-628. doi: 10.1016/j.agrformet.2010.02.002

Vockenhuber E a., Scherber C, Langenbruch C, et al. (2011) Tree diversity and environmental context predict herb species richness and cover in Germany's largest connected deciduous forest. Perspect Plant Ecol Evol Syst 13:111-119. doi: 10.1016/j.ppees.2011.02.004

Whittaker RH (1972) Evolution and Measurement of Species Diversity. Taxon 21:213-251. 
Table 1 Characteristics of ten oak stands within a $1363-\mathrm{km}^{2}$ area in the Central Pre-Pyrenees, Spain. Values are mean \pm standard error. ELEVAT = elevation, ORIENT = orientation $(\mathrm{S}=$ South, $\mathrm{SE}=$ South East, $\mathrm{SW}=$ South West, $\mathrm{E}=$ East $)$, SLOP = slope, $\mathrm{STSIZE}=$ stand size, SHPCOMP = shape complexity, DENSITY = density, $\mathrm{QFAB}=$ . faginea abundance, $\mathrm{DBH}=$ diameter at breast height, TREHEIGHT $=$ tree height, $\mathrm{AGE}=$ mean stand tree age, CVAGE $=$ Coefficient of Variation of age of stand, FORTYPE $=$ Forest type $(\mathrm{SF}=$ secondary forest, $\mathrm{CS}=$ abandoned coppice stand $)$

\begin{tabular}{|c|c|c|c|c|c|c|c|c|c|c|}
\hline $\begin{array}{l}\text { Stand characteristics/stand } \\
\text { locations }\end{array}$ & Rasal (RA) & Belsué (BE) & Abena $(\mathrm{AB})$ & Ara (AR) & Lucera (LU) & Ibort (IB) & Ipies (IP) & Nocito (NO) & Arguis (AG) & Rapun (RP) \\
\hline \multicolumn{11}{|l|}{ Topography } \\
\hline ELEVAT (m a.s.l.) & $868.3 \pm 4.8$ & $1158.5 \pm 1.20$ & $970.3 \pm 1.50$ & $971.1 \pm 2.00$ & $1198.0 \pm 7.70$ & $950.8 \pm 2.60$ & $852.5 \pm 2.30$ & $1046.7 \pm 2.10$ & $1026.2 \pm 1.90$ & $923.3 \pm 2.40$ \\
\hline ORIENT & S & $S$ & $S$ & SE & $\mathrm{SE}$ & $S$ & $\mathrm{E}$ & SW & S & SW \\
\hline SLOP $\left({ }^{\circ}\right)$ & $9.3 \pm 0.50$ & $30.5 \pm 0.40$ & $11.7 \pm 0.50$ & $19.6 \pm 0.50$ & $16.8 \pm 1.20$ & $14.8 \pm 1.10$ & $7.8 \pm 0.60$ & $25.0 \pm 0.80$ & $11.0 \pm 0.60$ & $17.98 \pm 1.40$ \\
\hline \multicolumn{11}{|l|}{ Spatial attributes } \\
\hline STSIZE (ha) ${ }^{a}$ & 114 & 94 & 73 & 244 & 1115 & 40 & 146 & 294 & 1847 & 217 \\
\hline SHPCOMP (perimeter/area) ${ }^{a}$ & 126.41 & 119.60 & 77.49 & 164.23 & 244.28 & 103.17 & 268.11 & 267.27 & 232.38 & 204.62 \\
\hline \multicolumn{11}{|l|}{ Forest structure } \\
\hline DENSITY (stems ha-1) & $607 \pm 0.20$ & $1100 \pm 0.10$ & $999 \pm 0.10$ & $503 \pm 0.30$ & $867 \pm 0.10$ & $1088 \pm 0.10$ & $812 \pm 0.10$ & $983 \pm 0.10$ & $818 \pm 0.10$ & $540 \pm 0.10$ \\
\hline QFAB (Tree/Transect) & $239 \pm 43$ & $362 \pm 15$ & $339 \pm 18$ & $133 \pm 32$ & $173 \pm 14$ & $426 \pm 7$ & $193 \pm 8$ & $389 \pm 28$ & $381 \pm 13$ & $212 \pm 18$ \\
\hline $\mathrm{DBH}(\mathrm{cm})$ & $14.00 \pm 1.40$ & $9.0 \pm 0.70$ & $13.3 \pm 1.30$ & $7.2 \pm 0.50$ & $12.0 \pm 0.80$ & $13.3 \pm 0.80$ & $11.4 \pm 0.70$ & $12.3 \pm 1.70$ & $13.0 \pm 1.40$ & $6.8 \pm 0.50$ \\
\hline TREHEIGHT (m) & $5.10 \pm 0.40$ & $4.8 \pm 0.30$ & $5.1 \pm 0.30$ & $3.4 \pm 0.20$ & $5.5 \pm 0.30$ & $6.1 \pm 0.20$ & $4.3 \pm 0.30$ & $5.5 \pm 0.41$ & $4.7 \pm 0.33$ & $3.9 \pm 0.25$ \\
\hline AGE (years) & $31 \pm 3$ & $40 \pm 4$ & $50 \pm 2$ & $35 \pm 1$ & $39 \pm 1$ & $63 \pm 2$ & $64 \pm 2$ & $56 \pm 5$ & $50 \pm 1$ & $69 \pm 2$ \\
\hline CVAGE (\%)d & 31 & 43 & 19 & 17 & 12 & 17 & 15 & 47 & 10 & 9 \\
\hline FORTYPE & $\mathrm{SF}$ & $\mathrm{CS}$ & SF & $\mathrm{CS}$ & $\mathrm{CS}$ & $\mathrm{CS}$ & $\mathrm{CS}$ & $\mathrm{SF}$ & $\mathrm{CS}$ & $\mathrm{CS}$ \\
\hline
\end{tabular}

a Calculated based on the distribution map of Q. faginea forests in the study area (for more details, see Kouba et al. 2011) 
Table 2 Hierarchical multiplicative partitioning of the alpha $\left({ }^{q} D_{\alpha}\right)$ and beta $\left({ }^{q} D_{\beta}\right)$ components of overall diversity $\left({ }^{q} D_{\gamma}\right)$ in ten $Q$. faginea forest stands in the Central Pre-Pyrenees, Spain. Diversity was quantified using the Hill Index $\left({ }^{q} D\right)$, with $q=0$ (all species are given equal weight) or $q=1$ (greater weight is given to common species). Deviations from null distributions (numbers within brackets) are expressed by dividing the observed values by the expected values. The p-values were obtained by comparing the observed values with the values generated by $10^{4}$ randomizations

\begin{tabular}{|c|c|c|c|c|c|c|}
\hline & \multicolumn{3}{|c|}{$q=0$} & \multicolumn{3}{|c|}{$q=1$} \\
\hline & Observed & Expected & $p$-value & Observed & Expected & $\mathrm{p}$-value \\
\hline$q D_{\alpha_{-} \text {transects }}$ & $62.88(0.52)$ & 120.09 & $<0.01$ & $17.31(0.57)$ & 30.27 & $<0.01$ \\
\hline${ }^{q} D_{\alpha \_ \text {stands }}$ & $93.70(0.58)$ & 159.73 & $<0.01$ & $20.58(0.65)$ & 31.49 & $<0.01$ \\
\hline$q D_{\beta_{-} \text {transects }}$ & $1.49(1.12)$ & 1.33 & $<0.01$ & $1.18(1.13)$ & 1.04 & $<0.01$ \\
\hline${ }^{q} D_{\beta_{-} \text {stands }}$ & $2.54(1.82)$ & 1.39 & $<0.01$ & $1.56(1.52)$ & 1.02 & $<0.01$ \\
\hline$q D_{\gamma \_ \text {study area }}$ & 238 & 238 & - & 32.12 & 32.12 & - \\
\hline
\end{tabular}


Table 3 Redundancy analysis of the forest structural and environmental factors that explained a significant amount of the variation in species composition of forbs and woody species (significant relationships are shown). " ${ }^{2}{ }^{2}$ adj $C u m$ " is the cumulative adjusted $R^{2}$ of the model; the values within brackets indicate the variance (\%) explained by each explanatory variable, " $\mathrm{R}^{2}$ adj" is the total explained variance $(\%)$ in each model. $A G E=$ Mean stand age CVAGE $=$ Coefficient of variation of tree age, $\mathrm{STSIZE}=$ Stand size, $\mathrm{SLOP}=$ slope, $\mathrm{QFAB}=Q$, fagine $a$ abundance

\begin{tabular}{lllll}
\hline Species group & Variables & $\mathrm{R}^{2}$ adj Cum & $\mathrm{F}$ & $\mathrm{p}$-value \\
\hline Forbs $\left(\mathrm{R}^{2}{ }_{\text {adj }}=44.2\right)$ & AGE & $0.10(10.6)$ & 2.65 & 0.01 \\
& QFAB & $0.19(08.9)$ & 2.41 & 0.02 \\
& CVAGE & $0.33(13.3)$ & 3.28 & 0.00 \\
& SLOP & $0.44(11.4)$ & 3.11 & 0.01 \\
Woody $\left(\mathrm{R}^{2}{ }_{\text {adj }}=43.8\right)$ & STSIZE & $0.12(11.7)$ & 2.65 & 0.01 \\
& QFAB & $0.23(11.4)$ & 2.67 & 0.01 \\
& AGE & $0.34(11.5)$ & 2.77 & 0.01 \\
& CVAGE & $0.44(9.2)$ & 2.46 & 0.02 \\
\hline
\end{tabular}




\section{Figure legends}

Fig. 1 Location of the study area within Europe (upper right panel), and the locations of the ten $Q$. faginea forest stands sampled in the Central Pre-Pyrenees, Spain (left panel). The location of the three floristic transects (FT) and the forest structural transect (ST) within each stand (lower right panel). $\mathrm{AB}=$ Abena, $\mathrm{AG}=$ Arguis, $\mathrm{AR}=\mathrm{Ara}, \mathrm{BE}=$ Belsué, $\mathrm{IB}=\mathrm{Ibort}, \mathrm{IP}=\mathrm{Ipies}, \mathrm{LU}=$ Lucera, $\mathrm{NO}=$ Nocito, $\mathrm{RA}=$ Rasal, $\mathrm{RP}=$ Rapun

Fig. 2 Hierarchical levels in the multiplicative partitioning of plant species diversity in ten oak forest stands in the Central Pre-Pyrenees, Spain

Fig. 3 The abundances of common species (expressed as median values) in ten $Q$. faginea forest stands ( $n=30$ transects) in the Central Pre-Pyrenees, Spain. Boxes indicate the 25th and 75th percentiles, and whiskers indicate the 5 th and 95 th percentiles

Fig. 4 The contributions of the alpha and beta components of diversity to total gamma diversity for two values of $q(0$ and 1$)$ assessed using multiplicative diversity partitioning of plant species within ten oak forest stands in the Central Pre-Pyrenees, Spain. Apha-transect $=$ within-transect diversity $\left({ }^{q} D_{\alpha \_ \text {transects }}\right)$, Beta-transect $=$ among-transects $\beta$-diversity $\left({ }^{9} D_{\beta \_ \text {transects }}\right)$, and Beta-stand $=$ amongstands $\beta$-diversity ( ${ }^{q} D_{\beta \_ \text {stands }}$ )

Fig. 5 Ordination plots of the significant forest structural and environmental factors and the composition of forbs and woody species within ten oak forest stands in the Central Pre-Pyrenees, Spain. Arrows indicate the direction of increasing values of significant forest structural and environmental variables. $\mathrm{AGE}=$ mean stand tree age, $\mathrm{CVAGE}=$ coefficient of variation of stand age, STSIZE $=$ stand size, $\mathrm{SLOP}=$ slope, $\mathrm{QFAB}=Q$. faginea abundance. The letter codes indicate the locations of plant species that had a correlation of $\geq 0.25$ to the ordination axes. Species presented are: Forbs (APHMON: Aphyllanthes monspeliensis, GLOBNU: Globularia nudicaulis, THALIC: 
Thalictrum alpinum, LINOSUB: Linum suffruticosum, TEUPY: Teucrium pyrenaicum, BUGRA: Bupleurum rigidum, CORIS: Coris monspeliensis, POTE: Polygala monspeliaca, GLOBVU: Globularia vulgaris, EPIPAC: Epipactis sp., MEDICA: Medicago minima, HIERACI: Hieracium pilosella, TRIPRA: Trifolium pretense, HEPAT: Hepatica nobilis, THALTUB: Thalictrum tuberosum, SANCHA: Santolina chamaecyparissus, HEDERA: Hedera helix, AQUIMIL: Achillea millefolium, SEDUAL: Sedum album, COREME: Coronilla emerus, TEUCHA: Teucrium chamaedrys, MEDILUP: Medicago lupulina, LATHCIC: Lathyrus cicero, GALUCI: Galium lucidum, VICSAT: Vicia sativa, ERYNCAM: Eryngium campestre, THAPSIA: Thapsia villosa); Woody (THYVUL: Thymus vulgaris, GENSCO: Genista scorpius, JUNOXY: Juniperus oxycedrus, PINSIL: Pinus sylvestris, HELIMA: Helianthemum marifolium, ARGYZA: Argyrolobium zanonii, FUMAPRO: Fumana procumbens, ECHIOR: Echinospartum horridum, FUMERI: Fumana ericifolia, STADUB: Staehelina dubia, QUEILE: Quercus ilex, ONOFRU: Ononis fruticosa, GENHIS. Genista hispanica, DORPEN: Dorycnium pentaphyllum, THYMELEA: Thymelaea pubescens, VIBLAN: Viburnum lantana, ACEMON: Acer monpessulanum, JUNCOM: Juniperus communis, LONXYL: Lonicera xylosteum, ARCUVA: Arctostaphylos uva-ursi, LONETRU: Lonicera etrusca, AMEOVA: Amelanchier ovalis, CYTSES: Cytisophyllum sessilifolium, BUXSEM. Buxus sempervirens). 
Fig. 1

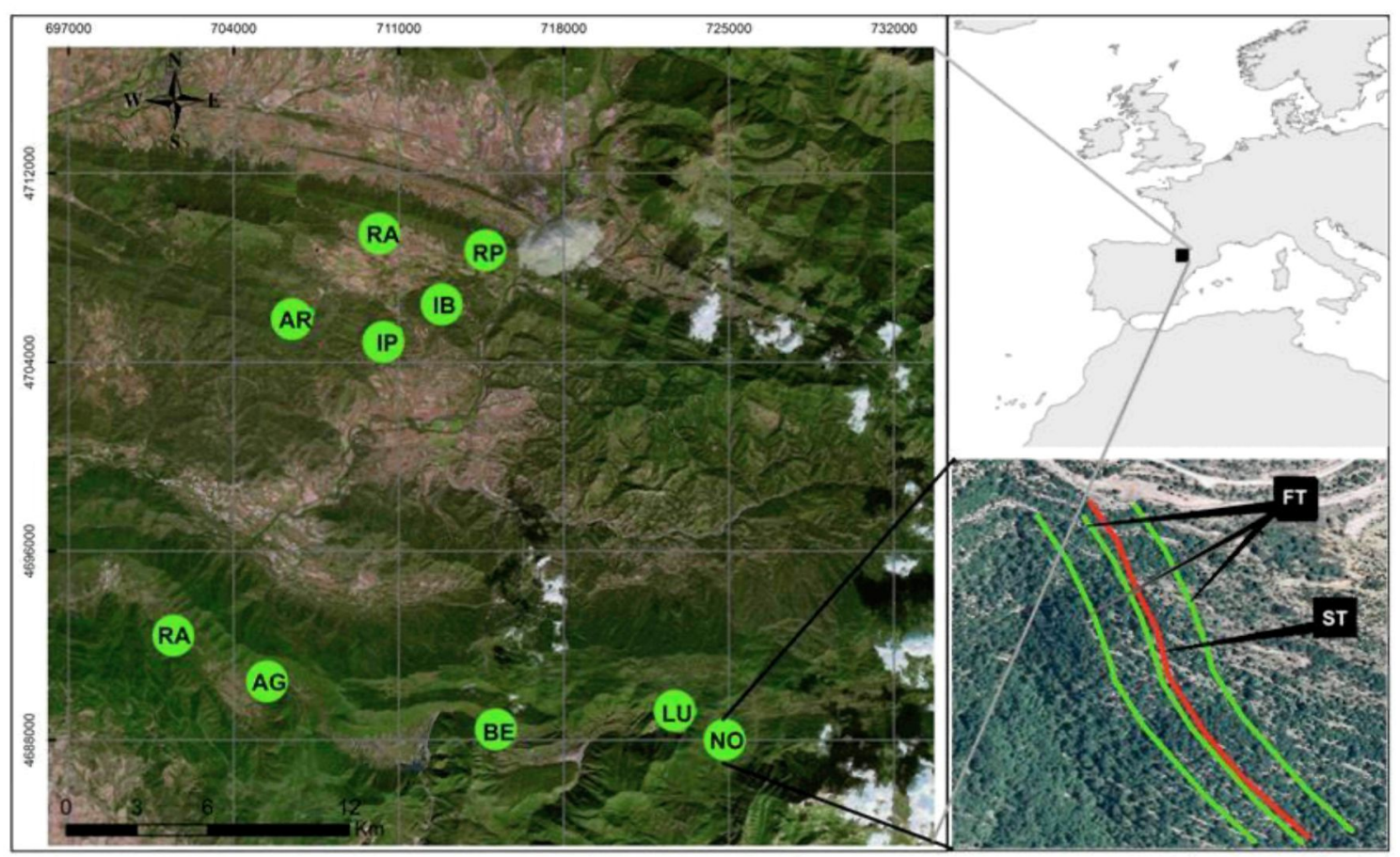


Fig. 2

Landscape level:

Total area $=1363 \mathrm{~km}^{2}$

Stand level:

10 stands (40 - 294 ha)

Distances between stands ranged from 3 to $25 \mathrm{~km}$

Transect level:

30 500-m transects ( $n=3$ per stand)

Distances between transects ranged from 0.05 to $25 \mathrm{~km}$
${ }^{q} D_{r_{\text {_tudy ace }}}$ :

Within-study area diversity

Average within-study area diversity

$$
{ }^{q} D_{\text {a_stands: }}
$$

Within-stand diversity Average within-stand diversity

$$
{ }^{q} D_{\alpha, \text { trmecest: }} \text { : }
$$

Within-transect diversity Average within-transect diversity

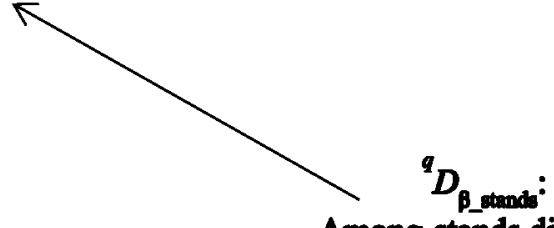

Among-stands diversity

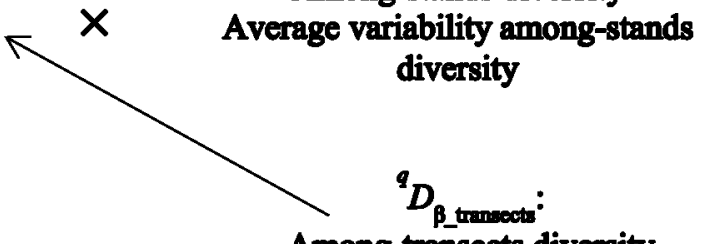

Among-transects diversity

$X \quad$ Average variability among-transects diversity 
Fig. 3

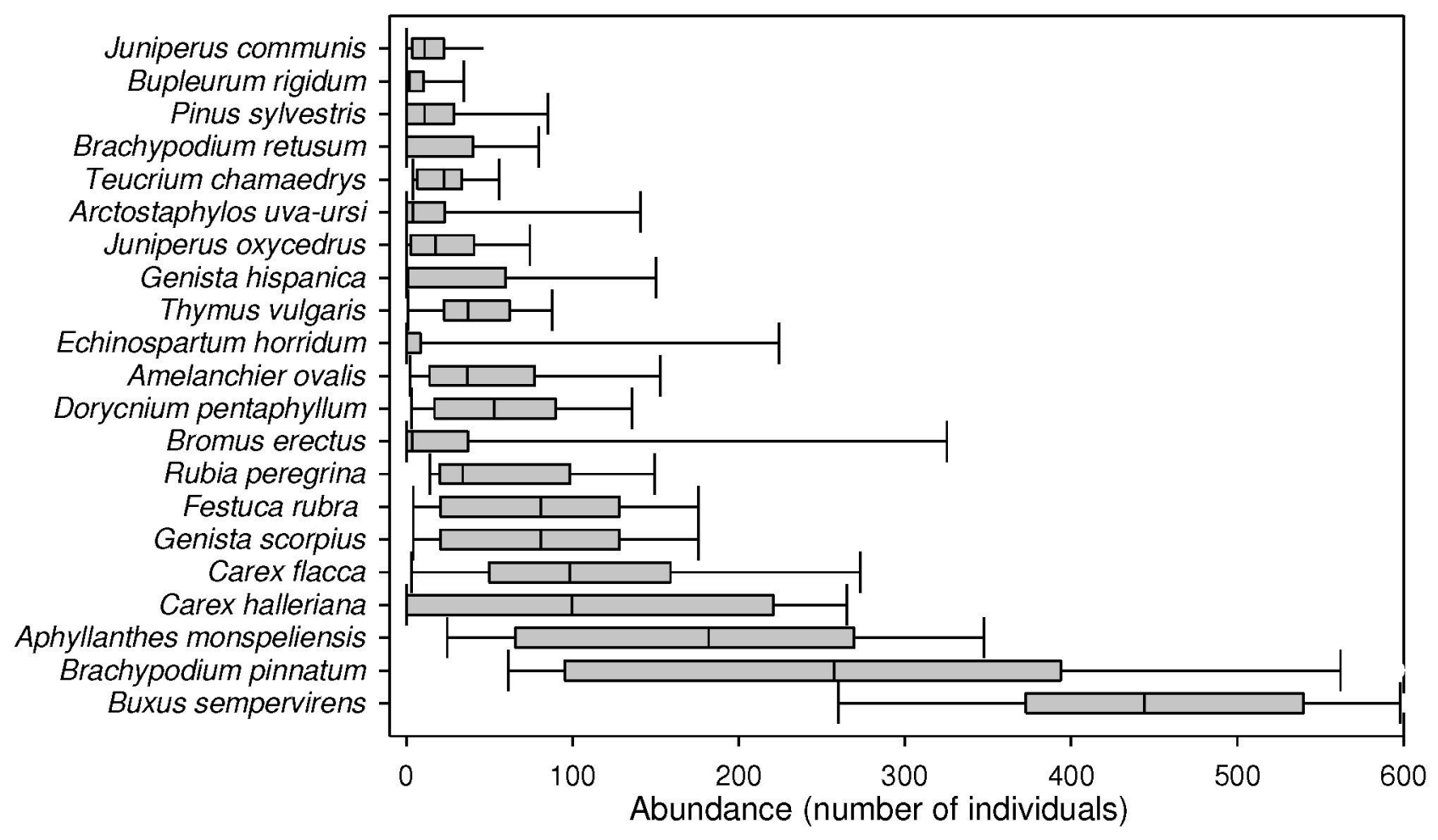


Fig. 4

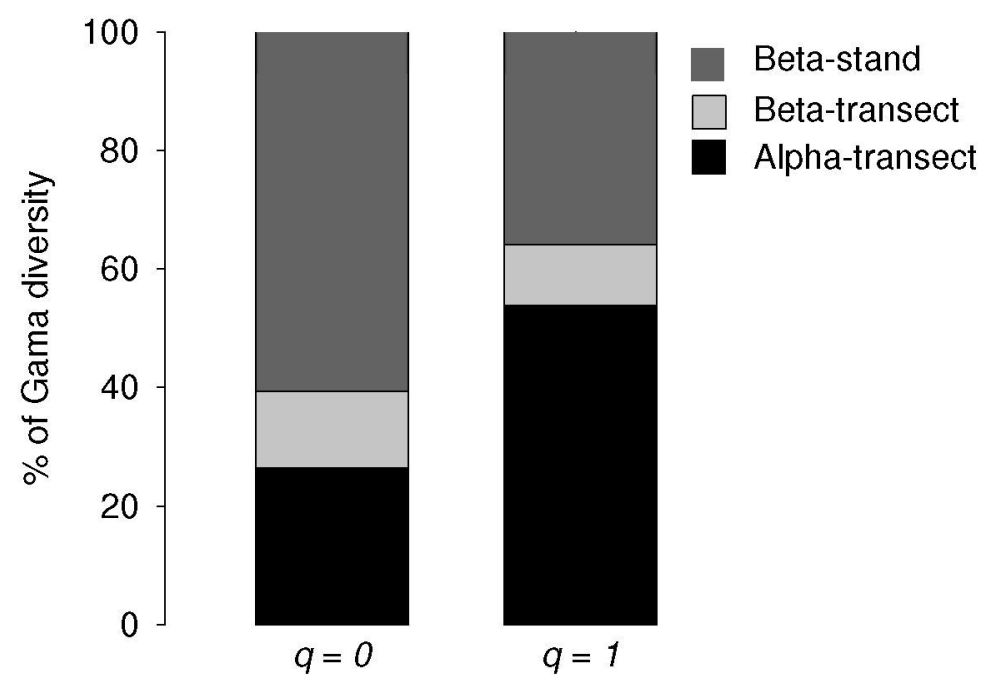


Fig. 5
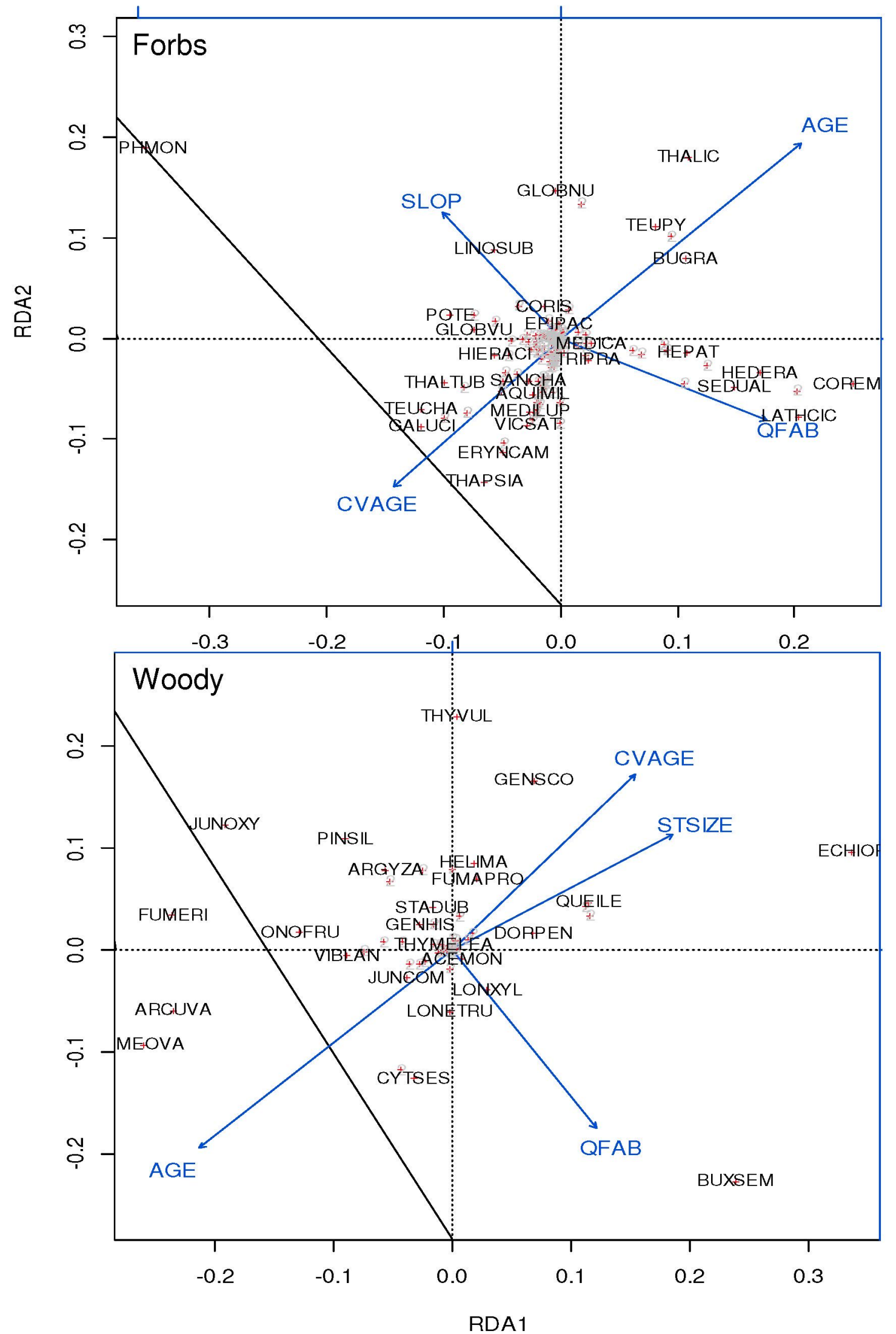
Appendix 1: The codes, scientific names, growth forms, abundance, and frequency (i.e., number of transects in which the species occurred) of the documented plant species in ten $Q$. faginea forest stands in the Central Pre-Pyrenees, Spain. Species are listed based on their abundance (lowest to highest)

\begin{tabular}{|c|c|c|c|c|}
\hline Code & Species scientific name & Growth form & Abundance $(\%)$ & $\begin{array}{l}\text { Frequency ( } \mathrm{n}^{\circ} \text { of } \\
\text { transects) }\end{array}$ \\
\hline ANVUL & Anthyllis vulneraria & Forb & 0.001 & 1 \\
\hline ARATUR & Arabis turrita & Forb & 0.001 & 1 \\
\hline ASPERULA & Asperula aristata & Forb & 0.001 & 1 \\
\hline BROTEC & Bromus tectorum & Graminoid & 0.001 & 1 \\
\hline CEPHARUB & Cephalanthera rubra & Forb & 0.001 & 1 \\
\hline CLEVIT & Clematis vitalba & Woody & 0.001 & 1 \\
\hline CROCNEV & Crocus nevadensis & Forb & 0.001 & 1 \\
\hline DIANTPUN & Dianthus pungens & Forb & 0.001 & 1 \\
\hline ECHIUM & Echium vulgare & Forb & 0.001 & 1 \\
\hline ERYSIRUS & Erysimum ruscinonense & Forb & 0.001 & 1 \\
\hline HELHAPE & Helianthemum apenninum & Forb & 0.001 & 1 \\
\hline HIPCOM & Hippocrepis comosa & Woody & 0.001 & 1 \\
\hline HYACINHIS & Hyacin thoides hispanica & Forb & 0.001 & 1 \\
\hline LATHSPHA & Lathyrus sphaericus & Forb & 0.001 & 1 \\
\hline LATHYSAX & Lathyrus saxatilis & Forb & 0.001 & 1 \\
\hline NARCISS & Narcissus sp. & Forb & 0.001 & 1 \\
\hline OPHRYS & Ophrys sp. & Forb & 0.001 & 1 \\
\hline ORCHUS & Orchis ustulata & Forb & 0.001 & 1 \\
\hline PLAMED & Plantago media & Forb & 0.001 & 1 \\
\hline PRUNVU & Prunella vulgaris & Forb & 0.001 & 1 \\
\hline RESEDA & Reseda lutea & Forb & 0.001 & 1 \\
\hline SALVER & Salvia verbenaca & Forb & 0.001 & 1 \\
\hline TAMUCOM & Tamus communis & Forb & 0.001 & 1 \\
\hline VALERI & Valerianella sp. & Forb & 0.001 & 1 \\
\hline VULUNI & Vulpia unilateralis & Graminoid & 0.001 & 1 \\
\hline ALLIUM1 & Allium sp. & Forb & 0.003 & 1 \\
\hline AVENBRO & Avenula bromoides & Graminoid & 0.003 & 1 \\
\hline CENTNIG & Centaurea nigra & Forb & 0.003 & 1 \\
\hline LINUCAM & Linum campanulatum & Forb & 0.003 & 1 \\
\hline PRUMA & Prunus mahaleb & Woody & 0.003 & 1 \\
\hline SORARI & Sorbus aria & Woody & 0.003 & 1 \\
\hline ARENAR & Arenaria leptoclados & Forb & 0.003 & 2 \\
\hline CAMPANULA & Campanula sp. & Forb & 0.003 & 2 \\
\hline CONOPOD & Conopodium sp. & Forb & 0.003 & 2 \\
\hline HELLFOE & Helleborus foetidus & Forb & 0.003 & 2 \\
\hline LONPERI & Lonicera periclymenum & Woody & 0.003 & 2 \\
\hline PLATBIF & Platanthera bifolia & Forb & 0.003 & 2 \\
\hline GENIS & Genista cinerea & Woody & 0.004 & 1 \\
\hline GEUSYLV & Geum sylvaticum & Forb & 0.004 & 1 \\
\hline LATHAPH & Lathyrus aphaca & Forb & 0.004 & 1 \\
\hline MEREMON & Merendera montana & Forb & 0.004 & 1 \\
\hline VERBA & Verbascum lychnitis & Forb & 0.004 & 1 \\
\hline BISCUTE & Biscutella valentina & Forb & 0.004 & 2 \\
\hline LINVIS & Linum viscosum & Forb & 0.004 & 2 \\
\hline VERORSI & Veronica orsiniana & Forb & 0.004 & 2 \\
\hline THYMPUB & Thymelaea pubescens & Woody & 0.004 & 3 \\
\hline CEPHALEU & Cephalaria leucantha & Forb & 0.006 & 1 \\
\hline CRUCAN & Crucianella angustifolia & Forb & 0.006 & 1 \\
\hline PRUNHYS & Prunella hyssopifolia & Forb & 0.006 & 1 \\
\hline ALYSALY & Alyssum alyssoides & Forb & 0.006 & 2 \\
\hline BRASYL & Brachypodium sylvaticum & Graminoid & 0.006 & 2 \\
\hline GERAROB & Geranium robertianum & Forb & 0.006 & 2 \\
\hline ORCHY & Orchis sp. & Forb & 0.006 & 3 \\
\hline TARAXA & Taraxacum sp. & Forb & 0.006 & 3 \\
\hline BERVU & Berberis vulgaris & Woody & 0.007 & 2 \\
\hline SORBUS & Sorbus sp. & Woody & 0.007 & 2 \\
\hline ORIVUL & Origanum vulgare & Forb & 0.007 & 3 \\
\hline ARRHENATALB & Arrhenatherum album & Graminoid & 0.009 & 2 \\
\hline DIGIPUR & Digitalis purpurea & Forb & 0.009 & 2 \\
\hline PRUNELLA & Prunellasp. & Forb & 0.009 & 2 \\
\hline SIBERHIR & Sideritis hirsuta & Woody & 0.009 & 2 \\
\hline TRIPRA & Trifolium pratense & Forb & 0.009 & 2 \\
\hline
\end{tabular}




\begin{tabular}{|c|c|c|c|c|}
\hline MELICI & Melica ciliata & Graminoid & 0.009 & 3 \\
\hline CENTALB & Centaurea alba & Forb & 0.010 & 2 \\
\hline HELVIO & Helian themum violaceum & Forb & 0.010 & 2 \\
\hline CIRSITUB & Cirsium tuberosum & Forb & 0.010 & 3 \\
\hline BLAKPER & Blakstonia perfoliata & Forb & 0.010 & 6 \\
\hline DIANT & Dianthus benearnensis & Forb & 0.010 & 6 \\
\hline POLYMONS & Polygala monspeliaca & Forb & 0.012 & 2 \\
\hline ARENASER & Arenaria serpyllifolia & Forb & 0.012 & 4 \\
\hline LEUCA & Leucanthemum pallens & Forb & 0.012 & 4 \\
\hline LEUCANTEMUN & Leucanthemun sp. & Forb & 0.012 & 4 \\
\hline EUCHA & Euphorbia characias & Forb & 0.012 & 5 \\
\hline CREPVIS & Crepis vesicaria & Forb & 0.013 & 2 \\
\hline PINNIG & Pinus nigra & Woody & 0.013 & 2 \\
\hline SORAUC & Sorbus aucuparia & Woody & 0.013 & 3 \\
\hline SILEVU & Silene vulgaris & Forb & 0.013 & 4 \\
\hline ARABIS & Arabis sp. & Forb & 0.013 & 5 \\
\hline RANUREP & Ranunculus repens & Forb & 0.015 & 2 \\
\hline CHEIRINT & Cheirolophus intybaceus & Woody & 0.015 & 4 \\
\hline PAROKAP & Paronychia kapela & Forb & 0.015 & 4 \\
\hline HELISTO & Helichrysum stoechas & Woody & 0.015 & 5 \\
\hline PRUNLAC & Prunella laciniata & Forb & 0.015 & 5 \\
\hline FI & Festuca indigesta & Graminoid & 0.016 & 2 \\
\hline INUMON & Inula montana & Forb & 0.016 & 3 \\
\hline EPIPAC & Epipactis sp. & Forb & 0.016 & 7 \\
\hline GERADIS & Geranium dissectum & Forb & 0.018 & 3 \\
\hline ONOSP & Ononis spinosa & Forb & 0.018 & 3 \\
\hline SCABAT & Scabiosa atropurpurea & Forb & 0.018 & 4 \\
\hline CLINOVU & Clinopodium vulgare & Forb & 0.018 & 5 \\
\hline BRIZA & Briza media & Graminoid & 0.018 & 6 \\
\hline HIEMURO & Hieracium murorum & Forb & 0.018 & 6 \\
\hline PHLEPRA & Phleum pratense & Forb & 0.019 & 2 \\
\hline THYFONT & Thymus fontqueri & Forb & 0.019 & 2 \\
\hline CEPHALARIS & Cephalaria sp. & Forb & 0.019 & 4 \\
\hline TRAPOG & Tragopogon $s p$ & Forb & 0.019 & 4 \\
\hline VICSEPI & Vicia sepium & Forb & 0.019 & 7 \\
\hline BRADIS & Brachypodium distachyon & Graminoid & 0.021 & 3 \\
\hline CORSCO & Coronilla scorpioides & Forb & 0.021 & 3 \\
\hline TRINIGLA & Trinia glauca & Forb & 0.021 & 6 \\
\hline ACEMON & Acer monpessulanum & Woody & 0.022 & 3 \\
\hline HYPEPER & Hypericum perforatum & Forb & 0.022 & 4 \\
\hline TRIFOL & Trifolium sp. & Forb & 0.022 & 5 \\
\hline ONONIS & Ononis sp. & Forb & 0.024 & 5 \\
\hline HELINUM & Helianthemum nummularium & Woody & 0.024 & 7 \\
\hline SCABIOSA & Scabiosa columbaria & Forb & 0.024 & 7 \\
\hline TEUCAP & Teucrium capitatum & Forb & 0.024 & 11 \\
\hline AGROCA & Agrostis capillaris & Graminoid & 0.025 & 1 \\
\hline LATHYLIN & Lathyrus linifolius & Forb & 0.025 & 2 \\
\hline LONETRU & Lonicera etrusca & Woody & 0.025 & 2 \\
\hline VICILATH & Vicia lathyroides & Forb & 0.025 & 2 \\
\hline VICCRA & Vicia cracca & Forb & 0.027 & 3 \\
\hline MEDI & Medicago sativa & Forb & 0.027 & 4 \\
\hline STIPERIO & Stipa eriocaulis & Graminoid & 0.027 & 4 \\
\hline AREMON & Arenaria montana & Forb & 0.027 & 6 \\
\hline QUECO & Quercus coccifera & Woody & 0.028 & 4 \\
\hline CEPHALB & Cephalanthera alba & Forb & 0.028 & 5 \\
\hline ERYGIU & Eryngium bourgatii & Forb & 0.028 & 6 \\
\hline PRIMULA & Primula sp. & Forb & 0.028 & 6 \\
\hline ASTRAMON & Astragalus monspessulanus & Forb & 0.028 & 7 \\
\hline ACHMIL & Achillea millefolium & Forb & 0.030 & 1 \\
\hline PLANTAG & Plantago sp. & Forb & 0.030 & 2 \\
\hline XERINA & Xeranthemum inapertum & Forb & 0.030 & 3 \\
\hline CORSAN & Cornus sanguinea & Woody & 0.031 & 4 \\
\hline STACHREC & Stachys recta & Forb & 0.031 & 4 \\
\hline RANUNC & Ranunculus sp. & Forb & 0.031 & 5 \\
\hline SANCHA & Santolina chamaecyparissus & Forb & 0.031 & 7 \\
\hline ASPCY & Asperula cynanchica & Forb & 0.031 & 8 \\
\hline ASTRA & Astragalus sp. & Forb & 0.033 & 5 \\
\hline PLANLAN & Plantago lanceolata & Forb & 0.034 & 3 \\
\hline GALVER & Galium verum & Forb & 0.036 & 4 \\
\hline HELHIR & Helian themum hirtum & Woody & 0.036 & 5 \\
\hline LOTUSCOR & Lotus corniculatus & Forb & 0.036 & 6 \\
\hline CONVCANT & Convolvulus cantabrica & Forb & 0.039 & 6 \\
\hline ARISTOPIS & Aristolochia pistolochia & Forb & 0.039 & 13 \\
\hline COLUTARB & Colutea arborescens & Woody & 0.040 & 3 \\
\hline
\end{tabular}




\begin{tabular}{|c|c|c|c|c|}
\hline LINUNAR & Linum narbonense & Forb & 0.043 & 10 \\
\hline POLYCAL & Polygala calcarea & Forb & 0.045 & 6 \\
\hline VIBLAN & Viburnum lantana & Woody & 0.046 & 6 \\
\hline CRUCIATA & Cruciata glabra & Forb & 0.048 & 4 \\
\hline LONXYL & Lonicera xylosteum & Woody & 0.048 & 8 \\
\hline MEDILUP & Medicago lupulina & Forb & 0.049 & 3 \\
\hline LATHYFIL & Lathyrus filiformis & Forb & 0.051 & 7 \\
\hline CATACA & Catananche caerulea & Forb & 0.052 & 7 \\
\hline THYMPRA & Thymus praecox & Forb & 0.054 & 7 \\
\hline LEUZEA & Leuzea conifera & Forb & 0.054 & 12 \\
\hline RHAALA & Rhamnus alaternus & Woody & 0.057 & 3 \\
\hline LAVANG & Lavandula angustifolia & Woody & 0.057 & 6 \\
\hline SCA & Scabiosa sp. & Forb & 0.057 & 11 \\
\hline VICSAT & Vicia sativa & Forb & 0.061 & 3 \\
\hline LAVAND & Lavandula latifolia & Woody & 0.064 & 11 \\
\hline TANACOR & Tanacetum corymbosum & Forb & 0.067 & 18 \\
\hline SEDUAL & Sedum album & Forb & 0.070 & 5 \\
\hline SAPOCY & Saponaria ocymoides & Forb & 0.075 & 11 \\
\hline SCORZO & Scorzonera aristata & Forb & 0.078 & 10 \\
\hline LITFRU & Lithodora fruticosa & Woody & 0.084 & 8 \\
\hline ANTHELI & Anthericum liliago & Forb & 0.087 & 6 \\
\hline KNAUTIA & Knautia arvensis & Forb & 0.091 & 9 \\
\hline RHASAX & Rhamnus saxatilis & Woody & 0.093 & 10 \\
\hline SANGUIMI & Sanguisorba minor & Forb & 0.094 & 16 \\
\hline JUNPHO & Juniperus phoenicea & Woody & 0.105 & 5 \\
\hline POTENEU & Potentilla neumanniana & Forb & 0.108 & 7 \\
\hline SEDUSE & Sedum sediforme & Forb & 0.108 & 18 \\
\hline THESDIV & Thesium divaricatum & Forb & 0.111 & 17 \\
\hline CORIS & Coris monspeliensis & Forb & 0.115 & 16 \\
\hline POA & Poa angustifolia & Graminoid & 0.118 & 12 \\
\hline VIO & Viola sp. & Forb & 0.120 & 7 \\
\hline HEDERA & Hedera helix & Forb & 0.124 & 3 \\
\hline ERYNCAM & Eryngium campestre & Forb & 0.127 & 7 \\
\hline STADUB & Staehelina dubia & Woody & 0.127 & 18 \\
\hline POLYGAL & Polygala alpestris & Forb & 0.132 & 15 \\
\hline ARRHENAT & Arrhenatherum elatius & Graminoid & 0.139 & 11 \\
\hline GLOBVU & Globularia vulgaris & Forb & 0.141 & 10 \\
\hline LATHCIC & Lathyrus cicera & Forb & 0.145 & 7 \\
\hline MEDICA & Medicago minima & Forb & 0.145 & 10 \\
\hline THAPSIA & Thapsia villosa & Forb & 0.156 & 8 \\
\hline GALIUM & Galium sp. & Forb & 0.162 & 12 \\
\hline CERASPUM & Cerastium pumilum & Forb & 0.165 & 2 \\
\hline VICINCA & Vicia incana & Forb & 0.166 & 8 \\
\hline ONONAT & Ononis natrix & Forb & 0.178 & 11 \\
\hline LINOSUB & Linum suffruticosum & Forb & 0.184 & 21 \\
\hline CYTSES & Cytisophyllum sessilifolium & Woody & 0.185 & 10 \\
\hline HEPAT & Hepatica nobilis & Forb & 0.191 & 11 \\
\hline EUPHSE & Euphorbia serrata & Forb & 0.200 & 18 \\
\hline COREME & Coronilla emerus & Forb & 0.206 & 10 \\
\hline BUPLE & Bupleurum ranunculoides & Forb & 0.217 & 5 \\
\hline FUMAPRO & Fumana procumbens & Woody & 0.230 & 9 \\
\hline VIOLA & Viola alba & Forb & 0.232 & 26 \\
\hline LIGVUL & Ligustrum vulgare & Woody & 0.236 & 13 \\
\hline FGL & Festuca glauca & Graminoid & 0.262 & 3 \\
\hline DACT & Dactylis glomerata & Graminoid & 0.271 & 13 \\
\hline HIERACI & Hieracium pilosella & Forb & 0.271 & 25 \\
\hline ONOBRY & Onobrychis vicififolia & Forb & 0.278 & 17 \\
\hline POTE & Potentilla sp. & Forb & 0.281 & 23 \\
\hline THALTUB & Thalictrum tuberosum & Forb & 0.283 & 10 \\
\hline RUBUS & Rubus sp. & Woody & 0.284 & 18 \\
\hline HIPPO & Hippocrepis ciliata & Forb & 0.287 & 27 \\
\hline AVENULA & Avenula pratensis & Graminoid & 0.319 & 14 \\
\hline PRUSPI & Prunus spinosa & Woody & 0.347 & 15 \\
\hline QUEILE & Quercusilex & Woody & 0.350 & 13 \\
\hline ROSA & Rosa sp. & Woody & 0.365 & 24 \\
\hline TEUPY & Teucrium pyrenaicum & Forb & 0.375 & 16 \\
\hline GALUCI & Galium lucidum & Forb & 0.407 & 15 \\
\hline ARGYZA & Argyrolobium zanonii & Woody & 0.407 & 24 \\
\hline HELIMA & Helianthemum marifolium & Woody & 0.414 & 23 \\
\hline GALEST & Galium estebanii & Forb & 0.437 & 21 \\
\hline FUMERI & Fumana ericifolia & Woody & 0.459 & 13 \\
\hline BRAPH & Brachypodium phoenicoides & Graminoid & 0.468 & 4 \\
\hline PSBI & Psoralea bituminosa & Forb & 0.470 & 22 \\
\hline CRAMON & Crataegus monogyna & Woody & 0.471 & 27 \\
\hline
\end{tabular}




\begin{tabular}{lllll} 
CORMIN & Coronilla minima & Woody & 0.495 & 18 \\
KOELERVAL & Koeleria vallesiana & Graminoid & 0.510 & 26 \\
ONOFRU & Ononis fruticosa & Woody & 0.536 & 10 \\
THALIC & Thalictrum alpinum & Forb & 0.540 & 20 \\
CARDUS & Carduus sp. & Forb & 0.554 & 2 \\
GLOBNU & Globularia nudicaulis & Forb & 0.576 & 14 \\
JUNCOM & Juniperus communis & Woody & 0.706 & 26 \\
BUGRA & Bupleurum rigidum & Forb & 0.742 & 17 \\
PINSIL & Pinus sylvestris & Woody & 1.016 & 18 \\
BRARE & Brachypodium retusum & Graminoid & 1.035 & 13 \\
TEUCHA & Teucrium chamaedrys & Forb & 1.162 & 30 \\
ARCUVA & Arctostaphylos uva-ursi & Woody & 1.200 & 16 \\
JUNOXY & Juniperus oxycedrus & Woody & 1.248 & 25 \\
CAREX & Carex sp & Graminoid & 1.536 & 10 \\
GENHIS & Genista hispanica & Woody & 1.750 & 17 \\
THYVUL & Thymus vulgaris & Woody & 1.984 & 28 \\
ECHIOR & Echinospartum horridum & Woody & 2.017 & 13 \\
AMEOVA & Amelanchier ovalis & Woody & 2.338 & 29 \\
DORPEN & Dorycnium pentaphyllum & Woody & 2.536 & 29 \\
BROMERE & Bromus erectus & Graminoid & 2.557 & 17 \\
RUBPER & Rubia peregrina & Forb & 3.424 & 30 \\
CAREXFLA & Carex flacca & Graminoid & 3.539 & 19 \\
FR & Festuca rubra & Graminoid & 3.673 & 30 \\
GENSCO & Genista scorpius & Woody & 4.132 & 30 \\
CAREXHAL & Carex halleriana & Graminoid & 5.215 & 19 \\
APHMON & Aphyllanthes monspeliensis & Forb & 7.839 & 30 \\
BRAPIN & Brachypodium pinnatum & Graminoid & 11.700 & 30 \\
BUXSEM & Buxus sempervirens & Woody & 19.664 & 30 \\
\hline
\end{tabular}


Appendix 2: species richness (Hill Index with exponent $q=0$ ) (A) and exponential of Shannon entropy (Hill index with exponent $q=1$ ) (B) for plant ecological groups found in the $Q$. faginea forest stands in the Central Pre-Pyrenees, Spain. Boxes depict the 25th and 75th percentiles, and whiskers represent the 5th and 95th percentiles
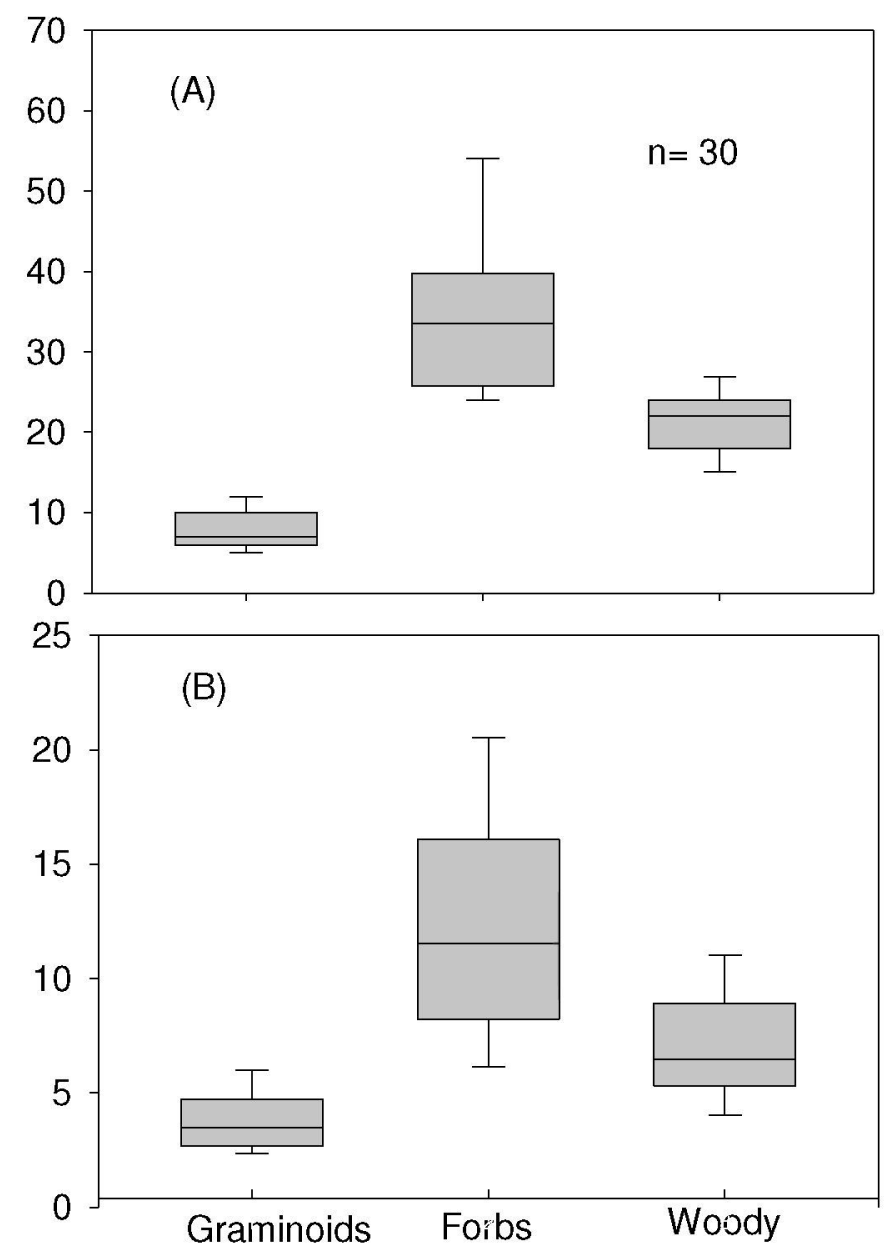